\title{
The real costs of acromegaly: analysis of different therapies
}

\author{
Michał Elbaum, Łukasz Mizera, Marek Bolanowski \\ Deptartment of Endocrinology, Diabetes and Isotope Therapy, Medical University Wroclaw, Poland
}

\begin{abstract}
Acromegaly is a rare, chronic condition caused by growth hormone (GH) overproduction, usually due to a benign tumour of the pituitary gland. During the disease many complications occur, including cardiovascular disease and changes in the musculoskeletal, respiratory, and endocrine systems. Treatment includes surgery, medical therapy, and radiation.

In this paper a literature review was conducted for information related to costs of management of acromegaly and its associated comorbidities using PubMed.

The majority of total costs represent pharmacological treatment, especially the most common somatostatin analogues (SSA) therapy. The average reported annual cost of SSA therapy is EUR $12,000-40,000$. Surgery reduces the cost of care via the possibility of avoiding lifelong pharmacological treatment. Radiotherapy is also suggested to lower the costs of therapy because about $60 \%$ of patients eventually will not require further pharmacological treatment; however, it is connected with negative outcomes like hypopituitarism, lower quality of life, and increased mortality. Cabergoline and pegvisomant are the lowest and highest priced treatments, respectively, but the overall impact on the cost of therapy is minor due to less frequent usage of these drugs. It is hard to fully estimate the impact of comorbidities of acromegaly on financial burden because patients are treated for them many years before the diagnosis of the underlying pathology. The treatment cost of comorbidities is higher in uncontrolled patients.

Life-long treatment of acromegaly and its comorbidities is very expensive. Early diagnosis and successful treatment reduce direct and indirect costs. (Endokrynol Pol 2019; 70 (1): 74-79)
\end{abstract}

Key words: acromegaly; therapy; costs; pharmacoeconomics

\section{Introduction}

Acromegaly is a rare, chronic condition caused by overproduction of a growth hormone $(\mathrm{GH})$, usually due to benign tumour of the pituitary gland. It occurs with a frequency of 40-130 per million with 3-5 new cases per million every year. Recent population studies suggest a greater increase in prevalence of acromegaly than previously thought $[1,2]$. Slow growth rate and asymptomatic course of disease experienced by patients causes a 10-year delay in diagnosis. The disease is usually diagnosed in the $4^{\text {th }}-5^{\text {th }}$ decade of life, earlier in women than in men. During the disease many complications can occur, including cardiovascular diseases and changes in the musculoskeletal, respiratory, and endocrine systems. The metabolic effects of GH are mediated by insulin-like growth factor 1 (IGF-1). Additionally, the disease is accompanied by deterioration in the quality of the patient's life and an increase in the mortality rate, which is 1.5-2.5 times higher than among the general population [3-6]. Therefore, it is very important to diagnose and treat acromegaly early, giving the patients a chance to restore a life expectancy comparable to the normal population and improved quality of life.
Moreover, acromegaly is an expensive disease. Its cost intensity is related to modern diagnostics and therapy of acromegaly, but also the costs of disease complications and their management are very high and seem to be underestimated.

\section{Overall direct and indirect costs of acromegaly treatment}

In Sweden, Lesén et al. conducted a population study on a group of 358 patients treated between 1987 and 2013 for acromegaly. The average total cost of care was estimated at EUR 12,000 per patient per year. This sum consisted of direct costs in $77 \%$ of cases. The remaining part, and therefore a distinct minority, was indirect costs associated with the productivity loss due to sickness absence and mortality [7]. Similar annual direct costs were reported by the authors of other European studies from Italy and Spain - about EUR 8000-12,000 and EUR 10,000 per patient, respectively $[8,9]$.

There is a correspondence between studies assessing health care costs for acromegalic patients, that the vast majority of direct medical costs are caused by pharmacological treatment [7-9]. In the largest pub- 
lished research on this topic carried out by Lesén et al. medication accounted for $2 / 3$ of direct costs - twice as much as costs related to imaging, laboratory and ophthalmological assessment, stationary and outpatient specialist care, and surgical interventions taken together [7].

In Poland, Orlewska et al. carried out a prospective study on a group of 139 patients treated for acromegaly with lanreotide autogel. The total direct annual treatment costs per patient were estimated at PLN 50,692 (about EUR 12,000). 97\% of the costs were pharmacological treatment. Other direct costs, not connected to pharmacotherapy, included: outpatient care (49\%), hospitalisation (23\%), diagnostic tests $(20 \%)$, and laboratory tests $(8 \%)$ [10].

\section{Surgical treatment}

Surgical treatment is the preferable first-line treatment in most patients with acromegaly. It is indicated in cases with fully resectable tumour or during vision impairment caused by optic chiasm compression. The treatment may also be considered if the lesion cannot be removed completely, regardless of the optic chiasm engagement because this may increase the effectiveness of subsequent pharmacological treatment, particularly in patients with highly active disease [3, 11]. Karavitaki et al. showed an improvement in GH and IGF-1 responses in the case of previous surgical reduction of tumour mass from 31 to $69 \%$ and from 42 to $89 \%$, respectively [12].

The effectiveness of the surgery depends on the size and location of the tumour, as well as the initial GH concentration. Improved surgical outcomes have been demonstrated when the treatment is carried out in specialised centres by an experienced operator performing at least 50 procedures per year. The remission rate in such centres is $>85 \%$ for microadenomas, $40-50 \%$ for macroadenomas, and $25-30 \%$ for invasive macroadenomas [11, 13].

Surgery potentially reduces the cost of total long-term care for an acromegalic patient due to the possibility of avoiding life-long pharmacological treatment, which forms the key financial burden. In a study conducted by Roset et al., during the two-year follow-up the costs generated by only surgically treated patients were assessed at EUR 2501 per year per person, whereas only pharmacologically treated costs were EUR 9745 per person per year [9]. Luque-Ramirez et al. also confirmed the financial benefits of successful surgery. The authors investigated expenditure on the management of patients with invasive macroadenomas. The cost of the neurosurgical admission and surgery was EUR 8404. Among the 11 subjects, once treatment was radical, the annual cost for these patients was EUR 1343 per patient per year in a two-year follow-up. The average costs in the entire study population were EUR 7570 per patient per year. Thus, the higher the success rate of surgery, the lower the cost of treatment [13]. Biermasz et al. calculated that with the effectiveness of the procedure at the level of $80 \%$ in relation to $60 \%$ lifelong costs for 100 patients decrease by more than three times [14]. The effectiveness of the procedure depends to a great extent on the surgeon's experience; hence, the strategy of referring a patient with acromegaly qualified for surgery to a specialized centre has, among others, also potential pharmacoeconomic justification. The surgical success rate is significantly lower in the case of macroadenomas. Therefore, it is not surprising that higher costs of therapy in this group have been demonstrated [9]. A factor potentially facilitating cost reduction would be early diagnosis of the disease that could, in theory, allow the disease to be captured at the microadenoma stage in a greater number of patients. Unfortunately, the delay of diagnosis is now significant and the time from the first symptoms of the disease to the treatment often exceeds 10 years [15]. Therefore, it seems justified to conduct a procedure aimed at increasing the awareness of physicians, especially of primary care, as well as among patients, on the subject of acromegaly, especially because many of the symptoms, such as enlargement of the hands, feet, prognathism, soft tissue hypertrophy or bilateral carpal tunnel syndrome, are quite specific to this disease, and usually these are among the first manifestations $[3,16]$. Early diagnosis of the disease would also allow avoidance of the costs of prolonged treatment of the complications of acromegaly before its diagnosis, which constitute a significant part of expenditure on care for patients with this entity [15].

Researchers from the Netherlands, in the study of Biermasz et al., reported that a treatment algorithm including primary surgical treatment can reduce the direct cost of treatment by $30 \%$ in relation to the algorithm in which the procedure is performed as a second-line therapy, and $46-59 \%$ compared to medical treatment only. The authors estimated the costs of a single surgery in the Netherlands is approx. EUR 12,000. For comparison, the annual costs for pharmacological treatment ranged between approximately EUR 7900 and 84,900 per patient depending on the type and dose of the preparation [14]. Cost of single surgery in Poland in 2016, either transcranial or transsphenoidal, paid by the public payer was around PLN 15,450 (circa EUR 3450) [17]. The costs of neurosurgery in comparison to the costs of other therapies of acromegaly are shown in Figure 1. 


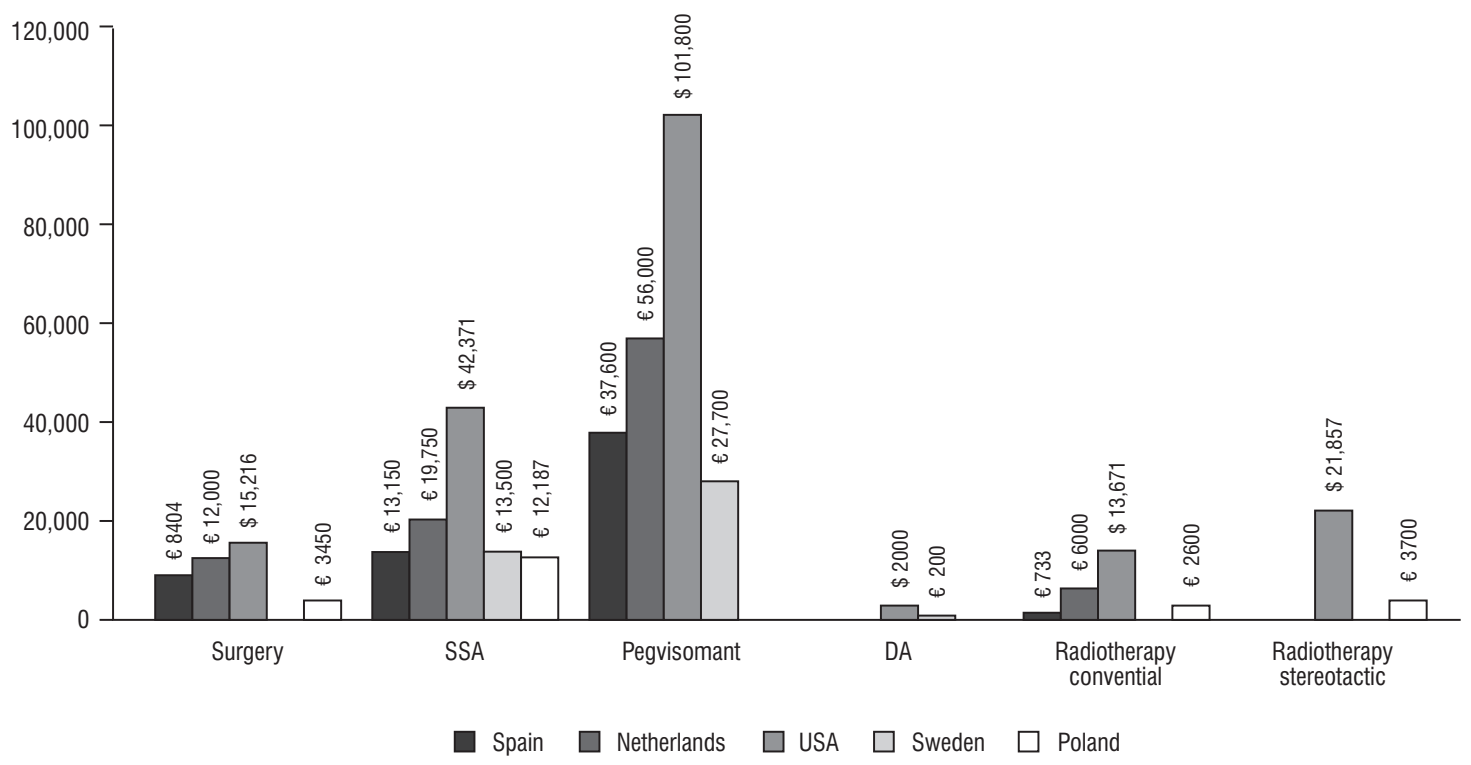

Figure 1. Comparison of mean costs of various therapies of acromegaly in different countries. Costs of medical therapy are shown as annual costs. Costs in USA given in US dollars (\$), other countries in euro (€). SSA — somatostatin analogues; DA - dopamine agonists

\section{Somatostatin analogues}

Somatostatin analogues (SSA) or somatostatin receptor ligands are used as the primary medical treatment in cases where the chances of neurosurgical procedures being not effective are high or surgical treatment was non-radical. Long-acting forms are used, most often lanreotide autogel (Somatuline Autogel, Ipsen) and octreotide LAR (Sandostatin LAR, Novartis). The effectiveness of both drugs is comparable and varies from 40 to $85 \%$ depending on the remission criteria adopted $[18,19]$. Treatment with SSA has also been shown to be connected with improved quality of life [20].

The costs of therapy with SSA differ among countries and are dependent on the price imposed by drug manufacturers and the costs of reimbursement imposed by a country. Marko et al. calculated annual costs of therapy with SSA in the United States of America. The average annual cost of a therapy for lanreotide was USD 41,216 and USD 43,526 for octreotide. The cost of lifelong therapy estimated with average age of a patient at the time of diagnosis and average duration of a disease was USD 1,578,567 for lanreotide and USD 1,667,052 for octreotide [18].

In the study published by Lesén et al. the annual cost of SSA therapy in Sweden in 2013 was estimated at EUR 13,500 [7]. In a paper of Orlewska et al. the annual average cost of lanreotide Autogel $120 \mathrm{mg}$ therapy in Poland was calculated at PLN 48,750 (EUR 12,187) [10]. In an analysis by Biermasz et al. the cost of SSA therapy in the Netherlands was presented at EUR 16,500 for octreotide LAR (with average dose of $24 \mathrm{mg} / 4$ weeks) and EUR 23,000 for lanreotide Autogel (average dose of $103 \mathrm{mg} / 4$ weeks) [14]. Margusino-Framiñán et al. estimated that mean cost of one year of postoperative treatment for a patient not cured after surgery was around EUR 13,150 [21].

In patients treated with SSA procedures, to ensuring reduction of costs, attempts are made to reduce the dosage or increase the intervals between injections for patients with positive response to the drug. In the LEAD study, at the end of a 24-week treatment period, 110 of 124 patients had normal IGF-1 levels with lanreotide Autogel $120 \mathrm{mg}$ injected every six weeks. At the end of the second phase of the study, 94 of 124 patients were on six- or eight-week extended dosing intervals and had normal IGF-1 levels [22]. In the study of Biermasz et al. patients with controlled dosage regimen of octreotide LAR injections every four weeks, maintenance of effective reduction of $\mathrm{GH}$ levels in 13 out of 14 and effective normalisation of IGF-1 in $70 \%$ patients was observed with a dosage regimen of injections every six weeks. This treatment regimen reduced costs of drugs by 33\% [14]. During the research conducted by Turner et al., on 22 patients, the interval between consecutive dosages of the drug might have been prolonged past a four-week period for $91 \%$ of patients, past eight weeks for $27 \%$ of the patients, and with the treatment being effective and past 12 weeks for $14 \%$, which allowed the reduction of costs by $43 \%$ [23]. In the meta-analysis published by Margusino-Framiñán et al., in centres without optimal surgical results, preoperative treatment with SSA of GH-secreting pituitary macroadenomas was highly cost-effective and resulted in significant savings, one decade after 
surgery, of between EUR 9973 and EUR 31,733 for SSA and pegvisomant, respectively [21].

In the case of lanreotide autogel, self-administration of the drug is possible. With properly educated patients the forgoing treatment does not result in deterioration in control of the disease [24] but allows a slight decrease in costs of overall therapy due to non-involvement of health care system employees [25].

\section{Pegvisomant}

GH receptor antagonist - pegvisomant - is usually implemented when there is a suboptimal response to other treatment methods or in the case of their intolerance, although it is a possible therapeutic option also as a first-line medication [26]. It can be used alone or in combination with a somatostatin analogue. Treatment with pegvisomant is well-tolerated and is currently the most effective treatment available. It potentially allows control of the disease in up to $90 \%$ of patients with acromegaly $[18,27]$. As for SSA, this treatment modality has been shown to be connected with improved quality of life [20].

Although very effective, pegvisomant therapy is the most expensive of all forms of treatment. In the previously quoted Swedish study conducted by Lesén et al. [7] the cost of treatment in the group of patients who purchased pegvisomant at least once was EUR 27,700 per patient per year compared to 13,500 in the group that purchased SSA at least once. Biermasz et al. estimated that in the Netherlands the cost of therapy with pegvisomant exceeds 3-4 times the cost of SSA treatment. Precisely, yearly costs were reported as EUR 28,300-84,900 per patient for pegvisomant compared to EUR 7900-19,800 for SSA, depending on the dose of both used drugs [14]. In comparison, the mean annual cost of pegvisomant treatment in Spain was EUR 37,600 and in the USA USD 101,800 [21, 28].

Interestingly, as demonstrated by Jehle et al., time extension between consecutive doses of the drug may be a strategy of reducing costs of treatment with pegvisomant - similarly to treatment with SSA. The authors showed that 5 out of 10 patients did not require daily drug intake. In two subjects the injections could be used twice a week, in one every other day, and in the following two twice for three days while maintaining normalisation of the IGF-1 level for a 15-month average period of observation [29].

\section{Dopamine agonists}

Dopamine agonists were the first group of drugs used for acromegaly treatment. The main advantages of this group, despite their diminishing importance in the acromegaly treatment, are oral route of administration as well as low costs of therapy [30].

Recent guidelines recommend use of only cabergoline in the acromegaly therapy. Its effectiveness in biochemical control of the illness is estimated at circa $20-45 \%$ in affected patients with moderately increased levels of IGF-1 and GH [11, 31]. Cabergoline therapy can be considered for patients after failed surgery, who prefer oral medication and are affected with hyperprolactinaemia with moderately increased levels of IGF-1 and GH. The second indication is combined therapy with SSA in cases where monotherapy does not result in biochemical normalisation of the disease. Efficiency of combined therapy in terms of IGF- 1 normalisation is estimated at $42-60 \%$, and suppression of $\mathrm{GH}<2.5 \mu \mathrm{g} / \mathrm{L}$ is observed in $21-71 \%$ of patients whose levels had not normalised with SSA alone [11].

Yearly costs of cabergoline therapy in acromegaly were estimated at EUR 200 in Sweden and USD 2000 in the USA [7, 32]. The costs of medical therapies in comparison to costs of other therapies of acromegaly are shown in Figure 1.

\section{Radiotherapy}

Radiotherapy, due to its wide availability and high effectiveness of SSA therapy, is used as third- or, less frequently, as second-line therapy [32,33]. Most often it is used in patients after non-radical surgeries and/or with no biochemical control during pharmacological treatments. When used effectively, this method can lead to the cure of the disease or can limit the drugs needed for optimal control of the illness.

Conventional radiotherapy decreases the $\mathrm{GH}$ and IGF- 1 levels even in $60 \%$ of patients, but the time it takes to achieve the full effect is 10-15 years. During this time the patient still requires pharmacotherapy [29]. Stereotactic radiosurgery with Gamma Knife, CyberKnife, or linear accelerator usage enables biochemical remission of the disease in $40-60 \%$ of patients over the course of five years and reduction in tumour size in $93-100 \%$ patients over the course of five years [11,34].

The most common complication after radiotherapy is secondary hypopituitarism, which develops in $10-50 \%$ of patients over the course of 5-40 years after the treatment [11, 30]. In comparison with stereotactic radiosurgery, conventional radiotherapy is burdened with higher risk of developing additional complications, such as: cerebrovascular changes, radiation damages to the cranial nerves, cognitive impairments, or radiation necrosis [11]. The use of conventional radiotherapy in patients with acromegaly has also been associated with increased all-cause mortality [35] and lower quality of life [20]. 
The financial burden of radiotherapy in relation to other treatment modalities seems to be minor. Average cost of conventional radiotherapy was estimated at EUR 6000 in the Netherlands and EUR 733 in Spain $[13,14]$. In the study of Kimmell et al. overall costs of radiotherapy and SSA used to achieve the full effect of radiation in the USA were calculated. The cost of stereotactic radiosurgery and pharmacotherapy used during the course of five years was USD 191,857. The cost of conventional radiotherapy and eight years of pharmacotherapy was USD 285,671 [32]. Costs of radiotherapy in Poland range from PLN 11,700 (around EUR 2600) for conventional radiotherapy to PLN 16,600 (EUR 3700) for stereotactic radiosurgery [17].

Moreover, Biermasz et al. reported that implementation of radiotherapy in the treatment algorithm may result in lower overall cost of therapy, because about $60 \%$ of patients eventually will not require further pharmacological treatment normalising GH/IGF-1; however, the authors did not consider the potential costs connected with hypopituitarism [14]. The costs of radiotherapy in comparison to costs of other therapies of acromegaly are shown in Figure 1.

\section{Acromegaly and other diseases}

To present the costs of acromegaly treatment in a wider perspective, one might compare them to costs of other diseases. Due to different healthcare systems around the world this comparison is quite challenging.

In Sweden, based on combining many registries such as national patient registers, drug registers, cause of death registers, and sickness absence registers Lesén et al. concluded that the yearly cost of treatment for a patient with acromegaly is EUR 12,000 [7]. Using data from the same registries, yearly costs of type 1 and 2 diabetes treatment were estimated at EUR 3600 [36], costs of treatment of atrial fibrillation at EUR 5000 [37], costs of asthma treatment at EUR 1800 [38], and costs of treatment of breast and prostate cancer at EUR 55,400 and EUR 31,500, respectively [39].In a study by Placzek et al. in the USA the annual mean total all-cause medical and pharmacy costs of acromegaly management were USD 32,807 [40]. For comparison, treatment of Cushing's disease was estimated at circa USD 26,300-35,000 [41-43], treatment of diabetes at USD 12,282 [42], and treatment of hormonally inactive pituitary adenoma at USD 13,708 [41]. Yearly costs of medical treatment of prolactinomas was USD 3935 and USD 2622 for the first year and each additional year of treatment with bromocriptine, respectively. The average cost of cabergoline treatment was USD 6042 for the first year and USD 4729 for each additional year of treatment [44].

\section{Treatment of acromegaly complications}

In the study of Lesén et al. comorbidities comprised $55 \%$ of indirect costs from productivity loss but only $16 \%$ of the direct costs [7]. Nevertheless, it is difficult to fully estimate the impact of comorbidities of acromegaly on financial burden because patients are treated for some of them many years before the diagnosis of the underlying pathology. As Ben-Shlomo et al. proposed, it could possibly be calculated by assessing the average yearly treatment cost for each comorbidity connected with acromegaly, for example: vertebral fracture, sleep apnoea syndrome, etc., alone [45].

Didoni et al. documented that higher comorbidity burden and comorbidity treatment costs are reported in inadequately controlled patients compared to adequately controlled, which intuitively is expected. The overall treatment costs were also higher in the first mentioned group; however, fewer of them had neurosurgery performed, and the mean amount of SSA used was almost triple compared to adequately controlled patients. Thus, it seems that the drugs for acromegaly, not the treatment of comorbidities, were more responsible for the differences in the overall treatment costs between these two groups [8].

Early recognition and prompt treatment of acromegaly seems to be an unexcelled way in reducing comorbidity rate and subsequently treatment costs, especially because some of them, such as hypertension, diabetes, or arthropathy, once developed may not be fully reversible. Late diagnosis of acromegaly, together with tumour neurosurgery failure, lead to the necessity of life-long medical therapy and development of complications, loading the health service budget and limiting patients' ability of employment and well-being.

\section{References}

1. Chanson P, Salenave S, Kamenicky P, et al. Pituitary tumours: Acromegaly. Best Pract Res Clin Endocrinol Metab. 2009; 23(5): 555-574, doi: 10.1016/j.beem.2009.05.010, indexed in Pubmed: 19945023.

2. Daly AF, Rixhon M, Adam C, et al. High prevalence of pituitary adenomas: a cross-sectional study in the province of Liege, Belgium. J Clin Endocrinol Metab. 2006; 91(12): 4769-4775, doi: 10.1210/jc.2006-1668, indexed in Pubmed: 16968795.

3. Bolanowski M, Ruchała M, Zgliczyński W, et al. Acromegaly - a novel view of the patient. Polish proposals for diagnostic and therapeutic procedures in the light of recent reports. Endokrynol Pol. 2014; 65(4): 326-331, doi: 10.5603/EP.2014.0045, indexed in Pubmed: 25185857.

4. Fernandez A, Karavitaki N, Wass JAH. Prevalence of pituitary adenomas: a community-based, cross-sectional study in Banbury (Oxfordshire, UK). Clin Endocrinol (Oxf). 2010; 72(3): 377-382, doi: 10.1111/j.1365-2265.200 9.03667.x, indexed in Pubmed: 19650784.

5. Holdaway IM, Rajasoorya C. Epidemiology of acromegaly. Pituitary. 1999; 2(1): 29-41, indexed in Pubmed: 11081170.

6. Reid TJ, Post KD, Bruce JN, et al. Features at diagnosis of 324 patients with acromegaly did not change from 1981 to 2006: acromegaly remains under-recognized and under-diagnosed. Clin Endocrinol (Oxf). 2010; 72(2): 203-208, doi: 10.1111/j.1365-2265.2009.03626.x, indexed in Pubmed: 19473180 .

7. Lesén E, Granfeldt D, Houchard A, et al. Comorbidities, treatment patterns and cost-of-illness of acromegaly in Sweden: a register-linkage 
population-based study. Eur J Endocrinol. 2017; 176(2): 203-212, doi: 10.1530/EJE-16-0623, indexed in Pubmed: 27932528.

8. Didoni G, Grottol S, Gasco V, et al. Cost-of-illness study in acromegalic patients in Italy. J Endocrinol Invest. 2004; 27(11): 1034-1039, indexed in Pubmed: 15754735.

9. Roset M, Merino-Montero S, Luque-Ramírez M, et al. Cost of clinical management of acromegaly in Spain. Clin Drug Investig. 2012 32(4): 235-245, doi: 10.2165/11599680-000000000-00000, indexed in Pubmed: 22397307.

10. Orlewska E, Kos-Kudla B, Sowinski J, et al. Dosage and costs of lanreotide Autogel $120 \mathrm{mg}$ administered as part of routine acromegaly care in Poland - two years of data from Lanro-Study. Endokrynol Pol. 2015; 66(2): 142-148, doi: 10.5603/EP.2015.0022, indexed in Pubmed: 25931045.

11. Katznelson L, Laws ER, Melmed S, et al. Endocrine Society. Acromegaly: an endocrine society clinical practice guideline. J Clin Endocrinol Metab. 2014; 99(11): 3933-3951, doi: 10.1210/jc.2014-2700, indexed in Pubmed: 25356808.

12. Karavitaki N, Turner HE, Adams CBT, et al. Surgical debulking of pituitary macroadenomas causing acromegaly improves control by lanreotide. Clin Endocrinol (Oxf). 2008; 68(6): 970-975, doi: 10.1111/j.13 65-2265.2007.03139.x, indexed in Pubmed: 18031313.

13. Luque-Ramírez M, Paramo C, Varela da Costa C, et al. Cost of management of invasive growth hormone-secreting macroadenoma. J Endocrinol Invest. 2007; 30(7): 541-545, doi: 10.1007/BF03346346, indexed in Pubmed: 17848835.

14. Biermasz NR, Roelfsema F, Pereira AM, et al. Cost-effectiveness of lanreotide Autogel in treatment algorithms of acromegaly. Expert Rev Pharmacoecon Outcomes Res. 2009; 9(3): 223-234, doi: 10.1586/erp.09.17, indexed in Pubmed: 19527094.

15. Knutzen R, Ezzat $S$. The cost of medical care for the acromegalic patient. Neuroendocrinology. 2006; 83(3-4): 139-144, doi: 10.1159/000095521, indexed in Pubmed: 17047376.

16. Lugo G, Pena L, Cordido F. Clinical manifestations and diagnosis of acromegaly. Int J Endocrinol. 2012; 2012: 540398, doi: 10.1155/2012/540398, indexed in Pubmed: 22518126

17. Zarządzenie Prezesa Narodowego Funduszu Zdrowia z dnia 30 grudnia 2016 r. w sprawie określenia warunków zawierania i realizacji umów w rodzaju leczenia szpitalnego. http://nfz gov pl/zarzadzenia-prezesa/zarzadzenia-prezesa-nfz/zarzadzenie-nr-1292016dsoz.

18. Marko NF, LaSota E, Hamrahian AH, et al. Comparative effectiveness review of treatment options for pituitary microadenomas in acromegaly. J Neurosurg. 2012; 117(3): 522-538, doi: 10.3171/2012.4.JNS11739, indexed in Pubmed: 22725987.

19. Murray RD, Melmed S. A critical analysis of clinically available somatostatin analog formulations for therapy of acromegaly. J Clin Endocrinol Metab. 2008; 93(8): 2957-2968, doi: 10.1210/jc.2008-0027, indexed in Pubmed: 18477663.

20. Geraedts VI, Andela CD, Stalla GK, et al. Predictors of Quality of Life in Acromegaly: No Consensus on Biochemical Parameters. Front Endocrinol (Lausanne). 2017; 8: 40, doi: 10.3389/fendo.2017.00040, indexed in Pubmed: 28316591.

21. Margusino-Framiñán L, Pertega-Diaz S, Pena-Bello L, et al. Cost-effectiveness analysis of preoperative treatment of acromegaly with somatostatin analogue on surgical outcome. Eur J Intern Med. 2015; 26(9): 736-741, doi: 10.1016/j.ejim.2015.07.019, indexed in Pubmed: 26300269.

22. Neggers SJ, Pronin V, Balcere I, et al. Lanreotide Autogel $120 \mathrm{mg}$ at extended dosing intervals in patients with acromegaly biochemically controlled with octreotide LAR: the LEAD study. Eur J Endocrinol. 2015; 173(3): 313-323, doi: 10.1530/EJE-15-0215, indexed in Pubmed: 26047625.

23. Turner HE, Thornton-Jones VA, Wass JAH. Systematic dose-extension of octreotide LAR: the importance of individual tailoring of treatment in patients with acromegaly. Clin Endocrinol (Oxf). 2004; 61(2): 224-231, doi: 10.1111/j.1365-2265.2004.02084.x, indexed in Pubmed: 15272918

24. Bevan JS, Newell-Price J, Wass JAH, et al. Home administration of lanreotide Autogel by patients with acromegaly, or their partners, is safe and effective. Clin Endocrinol (Oxf). 2008; 68(3): 343-349, doi: 10.1111/j .1365-2265.2007.03044.x, indexed in Pubmed: 17892497.

25. Johanson V, Wilson B, Abrahamsson A, et al. Randomized crossove study in patients with neuroendocrine tumors to assess patient preference for lanreotide autogel(®) given by either self/partner or a health care professional. Patient Prefer Adherence. 2012; 6: 703-710, doi: 10.2147/PPA.S34337, indexed in Pubmed: 23118529.
26. Brue T, Castinetti F, Lundgren F, et al. ACROSTUDY investigators. Which patients with acromegaly are treated with pegvisomant? An overview of methodology and baseline data in ACROSTUDY. Eur J Endocrinol. 2009; 161 Suppl 1: S11-S17, doi: 10.1530/EJE-09-0333, indexed in Pubmed: 19684051

27. Trainer PJ, Drake WM, Katznelson L, et al. Treatment of acromegaly with the growth hormone-receptor antagonist pegvisomant. N Engl J Med. 2000; 342(16): 1171-1177, doi: 10.1056/NEJM200004203421604, indexed in Pubmed: 10770982.

28. Zhang JJ, Nellesen D, Ludlam WH, et al. Budget impact of pasireotide LAR for the treatment of acromegaly, a rare endocrine disorder. J Med Econ. 2016; 19(4): 374-385, doi: 10.3111/13696998.2015.1127816, indexed in Pubmed: 26629745.

29. Jehle S, Reyes CM, Sundeen RE, et al. Alternate-day administration of pegvisomant maintains normal serum insulin-like growth factor-I levels in patients with acromegaly. J Clin Endocrinol Metab. 2005; 90(3): 1588-1593, doi: 10.1210/jc.2004-1967, indexed in Pubmed: 15585549.

30. Melmed S, Colao A, Barkan A, et al. Acromegaly Consensus Group. Guidelines for acromegaly management: an update. J Clin Endocrinol Metab. 2009; 94(5): 1509-1517, doi: 10.1210/jc.2008-2421, indexed in Pubmed: 19208732.

31. Lee SY, Kim JH, Lee JiH, et al. The efficacy of medical treatment in patients with acromegaly in clinical practice. Endocr J. 2018; 65(1): 33-41, doi: 10.1507/endocri.EJ17-0125, indexed in Pubmed: 28931779.

32. Kimmell KT, Weil RJ, Marko NF. Multi-modal management of acromegaly: a value perspective. Pituitary. 2015; 18(5): 658-665, doi: 10.1007/s11102-014-0626-1, indexed in Pubmed: 25557288

33. Castinetti F, Morange I, Dufour $\mathrm{H}$, et al. Radiotherapy and radiosurgery in acromegaly. Pituitary. 2009; 12(1): 3-10, doi: 10.1007/s11102-007-0078-y, indexed in Pubmed: 18175223.

34. Gheorghiu ML. Updates in outcomes of stereotactic radiation therapy in acromegaly. Pituitary. 2017; 20(1): 154-168, doi: 10.1007/s11102-016-0783-5, indexed in Pubmed: 28210908

35. Ritvonen E, Löyttyniemi E, Jaatinen $\mathrm{P}$, et al. Mortality in acromegaly: a 20-year follow-up study. Endocr Relat Cancer. 2016; 23(6): 469-480, doi: 10.1530/ERC-16-0106, indexed in Pubmed: 27185871.

36. Bolin K, Gip C, Mörk AC, et al. Diabetes, healthcare cost and loss of productivity in Sweden 1987 and 2005 - a register-based approach. Diabet Med. 2009; 26(9): 928-934, doi: 10.1111/j.1464-5491.2009.02786.x, indexed in Pubmed: 19719715.

37. Ericson L, Bergfeldt L, Björholt I. Atrial fibrillation: the cost of illness in Sweden. Eur J Health Econ. 2011; 12(5): 479-487, doi: 10.1007/s10198-010-0261-3, indexed in Pubmed: 20593297.

38. Jansson SA, Rönmark E, Forsberg B, et al. The economic consequences of asthma among adults in Sweden. Respir Med. 2007; 101(11): 2263-2270, doi: 10.1016/j.rmed.2007.06.029, indexed in Pubmed: 17689234.

39. Lundqvist A, Andersson E, Steen Carlsson K. Costs of cancer in Sweden today and year 2040. Report in Swedish. IHE Rapport 2016: 1. https:/ ihe.se/publicering/kostnad-for-cancer/.

40. Placzek H, Xu Y, Mu Y, et al. Clinical and Economic Burden of Commercially Insured Patients with Acromegaly in the United States: A Retrospective Analysis. J Manag Care Spec Pharm. 2015; 21(12): 1106-1112, doi: 10.18553/jmcp.2015.21.12.1106, indexed in Pubmed: 26679960.

41. Swearingen B, Wu N, Chen SY, et al. Health care resource use and costs among patients with cushing disease. Endocr Pract. 2011; 17(5): 681-690, doi: 10.4158/EP10368.OR, indexed in Pubmed: 21454233.

42. Broder MS, Neary MP, Chang E, et al. Incremental healthcare resource utilization and costs in US patients with Cushing's disease compared with diabetes mellitus and population controls. Pituitary. 2015; 18(6): 796-802, doi: 10.1007/s11102-015-0654-5, indexed in Pubmed: 25841733

43. Broder MS, Neary MP, Chang E, et al. Burden of illness, annual healthcare utilization, and costs associated with commercially insured patients with Cushing disease in the United States. Endocr Pract. 2015; 21(1): 77-86, doi: 10.4158/EP14126.OR, indexed in Pubmed: 25148813.

44. Zygourakis CC, Imber BS, Chen R, et al. Cost-Effectiveness Analysis of Surgical versus Medical Treatment of Prolactinomas. J Neurol Surg B Skull Base. 2017; 78(2): 125-131, doi: 10.1055/s-0036-1592193, indexed in Pubmed: 28321375.

45. Ben-Shlomo A, Sheppard MC, Stephens JM, et al. Clinical, quality of life, and economic value of acromegaly disease control. Pituitary. 2011; 14(3) 284-294, doi: 10.1007/s11102-011-0310-7, indexed in Pubmed: 21597975. 


\title{
Rzeczywiste koszty akromegalii: analiza różnych terapii
}

\author{
Michał Elbaum, Łukasz Mizera, Marek Bolanowski \\ Katedra i Klinika Endokrynologii, Diabetologii i Leczenia Izotopami, Uniwersytet Medyczny im. Piastów Ślaskich we Wrocławiu
}

Artykuł jest tłumaczeniem pracy: Michat Elbaum, Eukasz Mizera, Marek Bolanowski. The real costs of acromegaly: analysis of different therapies. Endokrynol Pol 2019; 70 (1): 74-79.

Należy cytować wersję pierwotną.

Piśmiennictwo dostępne w wersji pierwotnej na stronach 78-79.

\section{Streszczenie}

Akromegalia jest rzadką, przewlekłą chorobą wywołaną nadmiernym wydzielaniem hormonu wzrostu (GH) najczęściej przez łagodnego gruczolaka przysadki. W przebiegu schorzenia dochodzi do wystąpienia licznych powikłań, $\mathrm{w}$ tym schorzeń sercowo naczyniowych, zmian w układzie kostno-mięśniowym, oddechowym i endokrynnym. Leczenie obejmuje: postępowanie chirurgiczne, farmakoterapię i radioterapię.

W pracy dokonano przeglądu literatury przy użyciu bazy PubMed w celu zdobycia informacji dotyczących kosztów leczenia akromegalii i związanych z nią powikłań.

Większość kosztów generowana jest przez farmakoterapię, głównie leczenie analogami somatostatyny (SSA). Średni roczny koszt terapii SSA to 12 000-40 000 euro. Leczenie operacyjne zmniejsza koszty opieki na skutek możliwości eliminacji dożywotniej farmakoterapii. Wprowadzenie radioterapii do algorytmu leczenia jest również rekomendowane w celu obniżenia kosztów leczenia, ponieważ $60 \%$ pacjentów, u których taką terapię zastosowano, nie będzie wymagało dalszego leczenia farmakologicznego. Wiąże się to jednak z negatywnymi skutkami, takimi jak: niedoczynnością przysadki, obniżoną jakością życia oraz podwyższoną śmiertelnością. Kabergolina i pegwisomant to odpowiednio najtańszy i najdroższy lek stosowany w terapii akromegalii, jednak całkowity wpływ tych leków na koszty jest mniejszy z uwagi na ich rzadsze stosowanie. Trudno jest ocenić całkowity wpływ powikłań akromegalii na obciążenie finansowe, ponieważ powikłania te są leczone na wiele lat przed rozpoznaniem właściwej choroby. Koszty leczenia powikłań są największe w grupie pacjentów z niedostateczną kontrolą choroby. Dożywotnie leczenia akromegalii i jej powikłań jest drogie. Wczesna diagnoza i skuteczne leczenie obniżają koszty pośrednie i bezpośrednie. (Endokrynol Pol 2019; 70 (1): 80-85)

Słowa kluczowe: akromegalia; terapia; koszty; farmakoekonomika

\section{Wstęp}

Akromegalia jest rzadką, przewlekłą chorobą wywołaną nadmiernym wydzielaniem hormonu wzrostu (GH, growth hormone) najczęściej przez łagodnego gruczolaka przysadki. Występuje z częstością 40-130 na milion oraz liczbą nowych zachorowań równą 3-5 na milion rocznie. Najnowsze badania populacyjne sugerują większą niż się wydawało częstość nowych przypadków [1,2]. Choroba ta ma powolny przebieg, przez długi czas jest nieodczuwalna przez pacjenta, co sprawia, że postawienie właściwej diagnozy może się opóźnić nawet 10 lat. Choroba jest rozpoznawana zwykle w 4.-5. dekadzie życia, wcześniej u kobiet niż mężczyzn. W przebiegu schorzenia dochodzi do wystąpienia licznych powikłań, w tym schorzeń sercowo-naczyniowych, zmian w układzie kostno-mięśniowym, oddechowym i endokrynnym. Efekty metaboliczne hormonu wzrostu są wywoływane przez insulinopodobny czynnik wzrostu 1 (IGF-1, insulin-like growth factor 1). Dodatkowo choro- bie towarzyszy pogorszenie jakości życia oraz zwiększona śmiertelność, która jest 1,5-2,5-krotnie większa niż w populacji ogólnej [3-6]. Z tego powodu ważna jest wczesna diagnoza i leczenie akromegalii, która daje pacjentowi szanse na przywrócenie oczekiwanej długości życia porównywalnej z występującą w zdrowej populacji oraz poprawę jakości życia.

Akromegalia jest także chorobą kosztochłonną. Wiąże się to z nowoczesną diagnostyką i leczeniem, ale również z kosztami powikłań i ich leczenia, które są bardzo wysokie i wydają się bagatelizowane.

\section{Bezpośrednie i pośrednie koszty medyczne opieki nad pacjentem z akromegalią}

W Szwecji Lesén i wsp. przeprowadzili badanie populacyjne obejmujące 358 pacjentów leczonych między 1987 a 2013 r. z powodu akromegalii. Średnie całkowite koszty opieki oceniono na 12000 euro rocznie na pacjenta. Spośród tego 77\% stanowiły koszty bezpo- 
średnie. Pozostałą część, a zatem wyraźną mniejszość, pośrednie koszty związane z utratą produktywności z powodu zgonów i wynikających z choroby absencji w pracy [7]. Zbliżone koszty bezpośrednie opisali autorzy innych europejskich opracowań z Włoch i Hiszpanii odpowiednio ok. 8000-12 000 euro oraz ok. 10000 euro rocznie na pacjenta $[8,9]$.

Istnieje zgodność między badaczami oceniającymi wydatki na opiekę zdrowotną nad pacjentami z akromegalią, iż zdecydowaną większość bezpośrednich kosztów medycznych stanowi leczenie farmakologiczne [7-9]. W największym dotychczas opublikowanym badaniu na ten temat, autorstwa Lesén i wsp., leki stanowiły $2 / 3$ bezpośrednich kosztów, dwukrotnie przewyższając koszty związane $\mathrm{z}$ badaniami obrazowymi, laboratoryjnymi, oceną okulistyczną, stacjonarną i ambulatoryjną opieką specjalistyczną i interwencjami chirurgicznymi razem wziętymi [7].

W Polsce Orlewska i wsp. przeprowadzili prospektywne badanie obejmujące 139 pacjentów z akromegalią leczonych lanreotydem Autogel. Całkowite roczne koszty leczenia 1 pacjenta oceniono na 50692 złotych (około 12000 euro). Wśród nich 97\% kosztów stanowiło leczenie farmakologiczne. Na pozostałe bezpośrednie koszty niezwiązane z farmakoterapią składały się: opieka ambulatoryjna (49\%), hospitalizacje (23\%), badania diagnostyczne $(20 \%)$, badania laboratoryjne $(8 \%)$ [10].

\section{Leczenie operacyjne}

Leczenie operacyjne stanowi podstawę terapii w większości przypadków pacjentów z akromegalią. Jest wskazane u chorych, u których możliwe jest całkowite usunięcie guza, a także $\mathrm{w}$ przypadku ucisku skrzyżowania wzrokowego przez gruczolak. Zabieg można również rozważyć w przypadku braku możliwości całkowitego usunięcia guza niezależnie od ucisku skrzyżowania wzrokowego, gdyż takie postępowanie może zwiększyć skuteczność późniejszego leczenia farmakologicznego, szczególnie u pacjentów z wysoce aktywną chorobą [3, 11]. Karavitaki i wsp. wykazali poprawę odpowiedzi w zakresie GH i IGF-1 z odpowiednio 31\% do $69 \%$ oraz z $42 \%$ do $89 \%$ w przypadku uprzedniego chirurgicznego zmniejszenia masy guza [12].

Skuteczność operacji zależy od wielkości i lokalizacji guza, a także wyjściowego stężenia GH. Wykazano lepsze efekty leczenia $\mathrm{w}$ przypadku leczenia przeprowadzanego $\mathrm{w}$ wyspecjalizowanych ośrodkach przez doświadczonego operatora wykonującego co najmniej 50 procedur rocznie. Skuteczność zabiegu w takich ośrodkach wynosi ponad 85\% dla mikrogruczolaków, 40-50\% dla makrogruczolaków i 25-30\% dla inwazyjnych makrogruczolaków [11, 13].
Operacja potencjalnie pozwala zmniejszyć koszty całkowitej długotrwałej opieki nad pacjentem z akromegalią ze względu na możliwość uniknięcia dożywotniego leczenia farmakologicznego stanowiącego główne obciążenie finansowe. $\mathrm{W}$ badaniu przeprowadzonym przez Roset i wsp. w trakcie 2-letniej obserwacji koszty leczenia pacjentów leczonych tylko chirurgicznie oceniono na 2501 euro rocznie na osobę, natomiast leczonych jedynie farmakologicznie - na 9745 euro na osobę rocznie [9]. Luque-Ramirez i wsp. również potwierdzili korzyści finansowe związane z przeprowadzeniem skutecznej operacji. Autorzy badali wydatki na leczenie pacjentów z inwazyjnymi makrogruczolakami. Koszty hospitalizacji i zabiegu neurochirurgicznego wynosiły 8404 euro. Wśród 11 badanych u jednego chorego zabieg był radykalny, roczne koszty w 2-letniej obserwacji $u$ tego pacjenta wynosiły 1343 euro rocznie. Średnie koszty w całej badanej populacji to 7570 euro rocznie na pacjenta. Zatem wraz z wzrostem odsetka powodzenia operacji obniżeniu ulegały koszty leczenia [13]. Biermasz i wsp. obliczyli, iż przy efektywności zabiegu na poziomie $80 \%$ w stosunku do $60 \%$ dożywotnie koszty na 100 pacjentów maleją ponad 3-krotnie [14]. Skuteczność zabiegu zależy w dużej mierze od doświadczenia chirurga, stąd strategia kierowania pacjenta z akromegalią zakwalifikowanego do operacji do wyspecjalizowanego ośrodka ma, poza innymi, również potencjalne uzasadnienie farmakoekonomiczne. Skuteczność zabiegu jest znamiennie niższa w przypadku makrogruczolaków. Nie dziwi zatem, iż wykazano większe koszty terapii $\mathrm{w}$ tej grupie [9]. Czynnikiem potencjalnie pozytywnie wpływającym na ich redukcję byłoby wczesne rozpoznanie choroby, teoretycznie u większej części pacjentów pozwalające na uchwycenie choroby na etapie mikrogruczolaka. Niestety opóźnienie rozpoznania pozostaje obecnie znaczne i czas od pierwszych objawów choroby do podjęcia leczenia często przekracza 10 lat [15]. Zasadne z tego powodu wydaje się postępowanie ukierunkowane na zwiększenie świadomości lekarzy, szczególnie podstawowej opieki zdrowotnej, jak również pacjentów, na temat akromegalii. Tym bardziej, iż wiele objawów, takich jak powiększenie dłoni, stóp, prognatyzm, przerost tkanek miękkich, czy obustronny zespół cieśni nadgarstka jest dość charakterystyczny dla tej choroby i zwykle właśnie te z nich stanowią pierwsze manifestacje choroby $[3,16]$. Strategie ukierunkowane na wczesne rozpoznanie choroby pozwoliłyby również na uniknięcie kosztów wieloletniego leczenia powikłań akromegalii przed jej rozpoznaniem, które stanowią istotną część wydatków na opiekę nad pacjentem [15].

W pracy Biermasz i wsp. badacze z Holandii wykazali, iż algorytm leczenia obejmujący pierwotne leczenie operacyjne może zmniejszyć bezpośrednie 


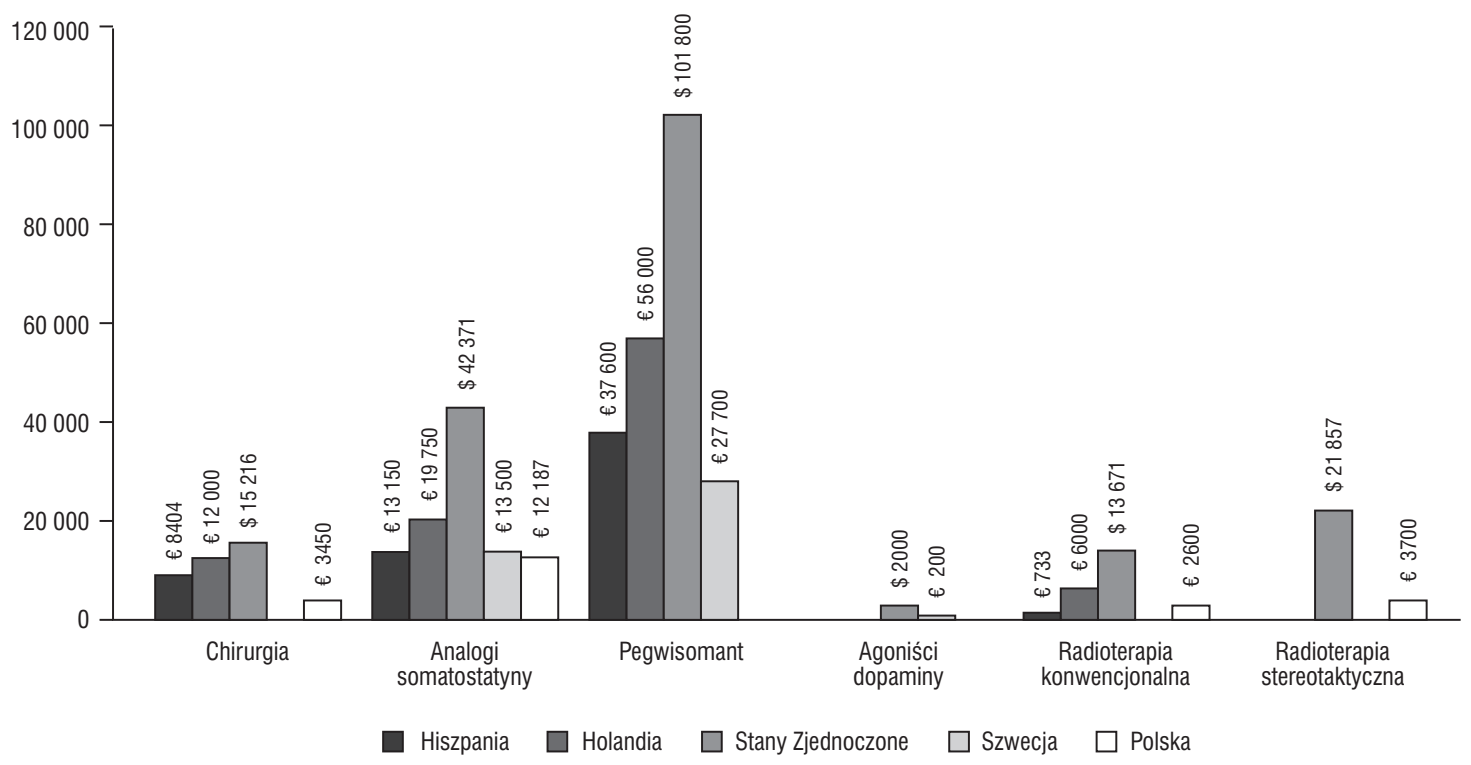

Rycina 1. Porównanie średnich kosztów różnych terapii akromegalii w różnych państwach. W przypadku farmakoterapii koszt odnosi się do jednego roku. Koszty $w$ Stanach Zjednoczonych podano w dolarach, pozostate - w euro

koszty terapii o $30 \%$ w stosunku algorytmu, w którym zabieg jest wykonywany jako leczenie drugiego rzutu, oraz o 46-59\% w stosunku do leczenia tylko farmakologicznego. Autorzy ocenili koszty jednorazowej operacji w Holandii na średnio ok. 12000 euro. Dla porównania roczne koszty dla leczenia farmakologicznego zawierały się w przedziale ok. 7900-84900 euro na pacjenta w zależność od rodzaju i dawki preparatu [14]. Koszty operacji w Polsce w 2016 r., zarówno z dostępu przezczaszkowego, jak i przezklinowego, poniesione przez publicznego płatnika wynosiły 15450 zł (ok. 3450 euro) [17]. Koszty leczenia operacyjnego w porównaniu z kosztami innych terapii akromegalii przedstawiono na rycinie 1 .

\section{Analogi somatostatyny}

Analogi somatostatyny (SSA, somatostatin analogues), ligandy receptora somatostatyny, stosuje się jako leczenie pierwszego rzutu w przypadkach, gdy szansa na pełne wyleczenie po leczeniu neurochirurgicznym jest mała lub leczenie operacyjne było nieradykalne. W terapii najczęściej wykorzystuje się preparaty o przedłużonym czasie działania: lanreotyd (Somatuline Autogel, Ipsen) oraz oktreotyd LAR (Sandostatin LAR, Novartis). Skuteczność obu leków jest porównywalna i wynosi od $40 \%$ do $85 \%$ w zależności od przyjętych kryteriów remisji $[18,19]$. Dowiedziono również, że leczenie z zastosowaniem SSA wpływa na poprawę jakości życia [20].

Koszty leczenia analogami różnią się między sobą w poszczególnych krajach i zależą od ceny narzuconej przez producenta oraz ustalanej przez państwo wysokości refundacji leku. W przeprowadzonym przez
Marko i wsp. badaniu wyliczono roczny koszt terapii SSA w Stanach Zjednoczonych. Średni roczny koszt terapii dla lanreotydu wynosił 41216 dolarów, a dla oktreotydu - 43526 dolarów. Oszacowany przez autorów na podstawie średniego wieku pacjenta w chwili rozpoznania i średniego czasu trwania choroby całkowity dożywotni koszt terapii lanreotydem wyniósł 1578 567, a oktreotydem - 1667052 dolarów [18].

W opublikowanym przez Leséna i wsp. badaniu roczny koszt terapii SSA w 2013 r. w Szwecji wyniósł 13500 euro [7]. W badaniu Orlewskiej i wsp. obliczono średni roczny koszt leczenia lanreotydem (Somatuline Autogel) w dawce $120 \mathrm{mg}$ w Polsce na $48750 \mathrm{zł}$ (12 187 euro) [10]. W analizie przygotowanej przez Biermasz i wsp. przedstawiono koszt terapii SSA w Holandii, dla oktreotydu LAR (przy średniej dawce $24 \mathrm{mg} / 4$ tygodnie) było to 16500 euro, a dla lanreotydu (średnia dawka $103 \mathrm{mg} / 4$ tygodnie) - 23000 euro [14]. Margusino-Framiñán i wsp. oszacowali, że średni koszt leczenia pooperacyjnego przez 1 rok u nieskutecznie zoperowanego pacjenta wynosił około 13150 euro [21].

U pacjentów leczonych SSA postępowaniem pozwalającym na redukcję kosztów jest próba zmniejszenia dawki lub wydłużanie odstępów między iniekcjami u pacjentów, u których występuje dobra odpowiedź na lek. W badaniu LEAD na koniec 24-tygodniowego okresu leczenia u 110 spośród 124 pacjentów stężenie IGF-1 po iniekcjach lanreotydu (Somatuline Autogel) podawanych w odstępach co 6 tygodni było prawidłowe. Na koniec drugiej fazy badania u 94 spośród 124 pacjentów zachowano 6- lub 8-tygodniowe odstępy między iniekcjami przy prawidłowym stężeniu IGF-1 [22]. W badaniu Biermasz i wsp. u pacjentów dobrze 
kontrolowanych, stosujących iniekcje oktreotydu LAR w schemacie co 4 tyg., obserwowano utrzymanie efektywnego obniżenia stężenia GH u 13 spośród 14 pacjentów, a u 70\% odnotowano normalizację stężenia IGF-1 przy podawaniu leku co 6 tyg. Taki schemat leczenia ograniczał koszty leku o 33\% [14]. W przeprowadzonym przez Turner i wsp. badaniu, obejmującym 22 pacjentów, przerwa między kolejnymi dawkami leku mogła być wydłużona powyżej 4 tyg. u 91\%, przy czym u $27 \%$ leczenie było efektywne przy stosowaniu leku co 8 , a u $14 \%$ co 12 tyg., co pozwalało na redukcję kosztów stosowania leku o 43\% [23]. W metaanalizie opublikowanej przez Margusino-Framiñán i wsp. wykazano, że w ośrodkach bez optymalnych wyników chirurgicznych, przedoperacyjne leczenie SSA u pacjentów z makrogruczolakiem przysadki wydzielającymi GH było wysoce opłacalne i przyniosło znaczne oszczędności, obserwowane jedną dekadę po operacji, wynoszące 9973 i 17733 euro, odpowienio dla SSA i pegwisomantu [21].

W przypadku stosowania preparatu lanreotydu w postaci roztworu do wstrzykiwań (Somatuline Autogel) możliwe jest samodzielne podawanie leku. W przypadku prawidłowo wyedukowanych pacjentów leczenie takie nie wpływa na pogorszenie kontroli akromegalii [24], a pozwala na niewielką redukcję kosztów opieki nad chorym ze względu na brak konieczności zaangażowania pracowników systemu ochrony zdrowia [25].

\section{Pegwisomant}

Pegwisomant - antagonista receptora hormonu wzrostu jest zwykle stosowany przy suboptymalnej odpowiedzi na pozostałe metody leczenia lub w przypadku ich nietolerancji, choć stanowi możliwą opcję terapeutyczną również jako lek pierwszego rzutu [26]. Może być zalecany $\mathrm{w}$ monoterapii lub $\mathrm{w}$ połączeniu z SSA. Leczenie z zastosowaniem pegwisomantu jest metodą leczenia dobrze tolerowaną i najskuteczniejszą z obecnie dostępnych, pozwala także na dobrą kontrolę choroby u ponad $90 \%$ osób dotkniętych akromegalią $[18,27]$. Podobnie jak $w$ przypadku SSA wykazano, iż ten rodzaj leczenia jest związany z pozytywnym wpływem na jakość życia pacjentów [20].

Terapia pegwisomantem, choć jest bardzo efektywna, stanowi najdroższą spośród wszystkich form leczenia. W cytowanym uprzednio badaniu szwedzkim przeprowadzonym przez Lesén i wsp. oceniono koszty leczenia w grupie, w której pacjenci choć raz wykupili pegwisomant, na 27700 euro rocznie $\mathrm{w}$ stosunku do 13500 euro dla grupy, w której badani choć raz wykupili SSA [7]. Biermasz i wsp. oszacowali, iż w Holandii koszty leczenia pegwisomantem 3-4-krotnie przewyż- szały koszty terapii z zastosowaniem SSA. Dokładnie wynosiły one 28 300-84 900 euro rocznie w przypadku pacjenta stosującego pegwisomant i ok. 7 900-19 800 euro u pacjenta przyjmującego SSA, w zależności od stosowanej dawki obu leków [14]. Dla porównania średni roczny koszt leczenia pegwisomantem w Hiszpanii wynosił 37600 euro, a w Stanach Zjednoczonych — 101 800 dolarów [21, 28].

Co ciekawe, jak zademonstrowali Jehle i wsp., wydłużenie czasu między kolejnymi dawkami leku — podobnie jak przy leczeniu z zastosowaniem SSA — może być strategią redukcji kosztów również u pacjentów leczonych pegwisomantem. Badacze wykazali, iż u 5 spośród 10 chorych nie była konieczna codzienna podaż leku. $U$ 2 badanych iniekcje mogły być stosowane 2 razy w tygodniu, u 1 co drugi dzień i kolejnych $2-$ dwa razy na 3 dni z zachowaniem normalizacji stężenia IGF-1 przez 15-miesięczny średni okres obserwacji [29].

\section{Agoniści dopaminy}

Agoniści dopaminy to pierwsza grupa leków stosowanych w leczeniu akromegalii. Głównymi ich zaletami, pomimo obecnie mniejszej roli w leczeniu tego schorzenia, jest doustna droga podawania oraz niski koszt terapii [30].

Aktualne wytyczne w leczeniu akromegalii zalecają stosowanie jedynie kabergoliny. Jej skuteczność $\mathrm{w}$ biochemicznej kontroli choroby ocenia się na ok. $20-45 \%$ u chorych z umiarkowanie podwyższonym stężeniem IGF-1 i GH [11, 31]. Terapię kabergoliną można rozważyć u chorych po nieskutecznym leczeniu operacyjnym, preferujących leczenie doustne i gdy występuje u nich hiperprolaktynemia, a wartości IGF-1 i GH są umiarkowanie podwyższone. Drugim wskazaniem jest terapia łączona z SSA, w przypadku gdy monoterapia nie przynosi biochemicznej normalizacji choroby. Skuteczność terapii łączonej ocenianej jako normalizacja IGF-1 wynosi około $42-60 \%$, a obniżenie stężenia GH < 2,5 $\mu \mathrm{g} / 1$ uzyskuje się u 21-71\% chorych, u których SSA okazał się nieskuteczny [11].

Roczny koszt terapii akromegalii kabergoliną w Szwecji wyniósł 200 euro, podczas gdy w Stanach Zjednoczonych było to 2000 dolarów [7, 32]. Koszty farmakoterapii w porównaniu z kosztami innych terapii akromegalii przedstawiono na rycinie 1 .

\section{Radioterapia}

Radioterapia, z uwagi na łatwy dostęp i dużą skuteczność SSA w leczeniu akromegalii, znalazła obecnie zastosowanie jako terapia trzeciego lub rzadziej drugiego rzutu [32, 33]. Najczęściej jest stosowana u pacjentów po nieradykalnym zabiegu operacyjnym i/lub z brakiem 
kontroli biochemicznej choroby w trakcie leczenia farmakologicznego. Skutecznie zastosowana może doprowadzić do wyleczenia lub zmniejszenia dawki leków wymaganych do optymalnej kontroli choroby.

Radioterapia konwencjonalna obniża stężenia GH i IGF-1 nawet u $60 \%$ chorych, jednak czas do osiągnięcia pełnego efektu wynosi 10-15 lat. W tym czasie u pacjenta w dalszym ciągu konieczna jest farmakoterapia [29]. Radiochirurgia stereotaktyczna z użyciem noża gamma (Gamma knife), noża cybernetycznego (CyberKnife) lub przyspieszacza liniowego umożliwia remisję biochemiczną choroby u 40-60\% pacjentów w ciągu 5 lat oraz redukcję rozmiarów guza u 93-100\% pacjentów w okresie 5 lat $[11,34]$.

Najczęstszym powikłaniem radioterapii jest wtórna niedoczynność przysadki rozwijająca się u 10-50\% pacjentów w ciągu 5-10 lat od zastosowania leczenia $[11,30]$. Radioterapia konwencjonalna jest dodatkowo obciążona większym niż radiochirurgia stereotaktyczna ryzykiem wystąpienia dodatkowych powikłań, takich jak: zmiany naczyniowo-mózgowe, popromienne uszkodzenie nerwów czaszkowych, zaburzeń funkcji poznawczych lub martwicy popromiennej [11]. Stosowanie konwencjonalnej radioterapii u pacjentów z akromegalią wiąże się ze zwiększoną śmiertelnością ogólną [35] i pogorszoną jakością życia [20].

Obciążenie finansowe kosztami radioterapii wydaje się nieduże w porównaniu $\mathrm{z}$ innymi dostępnymi metodami leczenia. Średni koszt radioterapii konwencjonalnej w Holandii wyniósł 6000 euro, a w Hiszpanii - 733 euro $[13,14]$. W analizie Kimmell i wsp. przedstawili całkowity koszt radioterapii oraz analogu stosowanego do osiągnięcia pełnego efektu napromieniania w Stanach Zjednoczonych. Koszt radiochirurgii stereotaktycznej oraz farmakoterapii stosowanej przez 5 lat wyniósł 191857 dolarów, a koszt radioterapii konwencjonalnej i 8-letniej farmakoterapii - 285671 dolarów [32]. Koszty radioterapii w Polsce wahają się od 11700 zł (ok. 2600 euro) w przypadku terapii konwencjonalnej do $16600 \mathrm{zł}$ (3700 euro) dla stereotaktycznej radiochirurgii [17].

Ponadto, jak wykazali Biermasz i wsp., zastosowanie radioterapii w leczeniu może skutkować ogólnym obniżeniem kosztów, ponieważ aż u niemal $60 \%$ pacjentów nie będzie konieczne farmakologiczne obniżania stężenia GH i IGF-1. Jednakże autorzy nie wzięli pod uwagę potencjalnych kosztów związanych z leczeniem niedoczynności przysadki [14]. Koszty radioterapii w porównaniu z kosztami innych terapii akromegalii przedstawiono na rycinie 1 .

\section{Akromegalia na tle innych chorób}

Aby przedstawić koszty leczenia akromegalii w szerszej perspektywie, można porównać je z kosztami innych jednostek chorobowych. Z uwagi na różne systemy ochrony zdrowia w poszczególnych krajach bezpośrednie porównanie kosztów leczenia różnych chorób jest trudne.

W Szwecji Lesén i wsp. na podstawie połączenia ze sobą licznych rejestrów, takich jak Narodowy Rejestr Pacjenta, Rejestr Leków, Przyczyn Zgonu, Nieobecności z Powodu Chorób, wyliczyli roczny koszt leczenia chorego z akromegalią na 12000 euro [7]. Wykorzystując powyższe rejestry obliczono roczne koszty terapii cukrzycy (typ 1 i 2) na 3600 euro [36], migotania przedsionków na 5000 euro [37], astmy na 1800 euro [38] oraz koszt leczenia raka piersi i gruczołu krokowego na odpowiednio 55400 i 31500 euro [39].

W Stanach Zjednoczonych w badaniu opracowanym przez Placzek i wsp. średni roczny całkowity koszt leczenia akromegalii wyniósł 32807 dolarów [40]. Leczenie choroby Cushinga kosztowało przy tym około 26 300-35 000 dolarów [41-43], cukrzycy - 12282 dolarów [42], a nieczynnego hormonalnie gruczolaka przysadki - 13708 dolarów [41]. Roczne koszty leczenia guza prolaktynowego to odpowiednio 3935 dolarów dla pierwszego roku i 2622 dolarów dla każdego następnego roku leczenia bromokryptyną. Średni koszt leczenia prolaktynoma kabergoliną to 6042 dolarów w pierwszym roku i 4729 dolarów w każdym następnym roku terapii [44].

\section{Leczenie powikłań akromegalii}

W badaniu Lesén i wsp. powikłania stanowiły 55\% wszystkich pośrednich kosztów związanych z utratą produktywności, ale tylko $16 \%$ kosztów bezpośrednich [7]. Trudno jednak jest ocenić całkowity wpływ powikłań akromegalii na obciążenie finansowe, ponieważ powikłania te są leczone na wiele lat przed rozpoznaniem właściwej choroby. Ben-Shlomo i wsp. sugerują, iż można by tę wartość oszacować poprzez ocenę średniego kosztu leczenia każdego z powikłań wynikających z akromegalii, np. złamań kręgów, zespołu obturacyjnego bezdechu śródsennego itp. [45].

Didoni i wsp. udokumentowali, zgodnie z przewidywaniami, że większe obciążenie powikłaniami i związane z nimi koszty występują częściej w grupie pacjentów z niedostateczną kontrolą choroby w porównaniu z grupą, w której schorzenie to jest dobrze kontrolowane. Całkowite koszty terapii były również wyższe w pierwszej wspomnianej wcześniej grupie, jednakże mniej należących do niej pacjentów przeszło zabieg neurochirurgiczny, a średnia liczba użytych SSA była 3-krotnie wyższa niż w grupie dobrze kontrolowanej. Wynika z tego, że to koszty leków na akromegalię, a nie koszty leczenia powikłań, złożyły się na różnicę w ogólnych kosztach 
leczenia pomiędzy wspomnianymi dwoma grupami [8]. Wczesne rozpoznanie i szybkie rozpoczęcie leczenia akromegalii zdaje się być najlepszym sposobem na redukcję występowania powikłań, a co się z tym wiąże, redukcję kosztów leczenia, zwłaszcza że niektóre z nich, m.in. nadciśnienie tętnicze, cukrzyca lub choroba zwyrodnieniowa, mogą być nieodwracalne w skutkach. Późna diagnoza akromegalii, wraz z nieskutecznym leczeniem operacyjnym, prowadzą do konieczności dożywotniej farmakoterapii, rozwijania się komplikacji zwiększających koszty ponoszone przez system opieki zdrowotnej, ograniczających możliwości zatrudnienia i normalnego funkcjonowania. 